\title{
Assessment of damage caused by rodents in some maize varieties in Farshut area, Qena governorate, Egypt
}

\author{
Elrawy A. A. A. ${ }^{{ }^{*}}$, Mahmoud N. A. ${ }^{a}$, Baghdadi S. A. S. ${ }^{\text {a }}$, Desoky A. S. S. ${ }^{\text {b }}$ \\ ${ }^{a}$ Agricultural Zoology and Nematology Department, Faculty of Agriculture, Al-Azhar University, Assiut, Egypt \\ ${ }^{b}$ Plant Protection Department, Faculty of Agriculture, Sohag University, Sohag, Egypt
}

\begin{abstract}
The work herein was carried out to estimate the damage caused by rodent species on some cultivars of yellow and white maize crop at EL-Dahasa village, Farshut district, Qena governorate, Egypt during the summer 2018 and 2019 seasons. The genotypes studied were three Yellow maize (Balady and Single Cross: S. C. 2055, S. C. 2066) and four white maize [ (Single cross: S. C. 4 and S. C. 6) and (three ways cross: T.W. C. 310 and T. W. C. 11)]. The Balady variety is more attacked by rodents compared to the single and triple hybrids, and this may be due to the early maturing variety (80-90 days) compared to the single and triple hybrids (110-120 days). Also, the yellow corn cultivars are more vulnerable to rodents than the white cultivars, due to the fact that they contain a greater amount of oils compared to the white cultivars.
\end{abstract}

Keywords: rodents, maize, hybrid variety, maturing variety, white cultivars. 


\section{Introduction}

Rodents are considered as one of the most important pests in Egypt. They cause great economic loss to farmers (damage the growing crops, stored products, poultry and animals farm); and to food manufactures by damaging the structure and fabric of buildings. Besides, they gnaw through almost any object in their ways to obtain food and shelter, Desoky (2018). Maize (Zea mays L.) is the third most cereal crop in the world, providing nutrient of humans and animals. The behavior of rodents can vary varies from place to place. Maize crop fields recorded as suitable host to rodent pests by many workers in the world (Abdel-Gawad et al., 2000; Ahmed, 2006; Baghdadi, 2012 Clark and Young, 1986; Desoky, 2018; ElSaady-Maha, 2009; Fiedler, 1994; Keshta, 1996; Metwally et al., 2009; Mulungu et al., 2005). The aim of this study is to determine the extent of infestation of the most important types of maize white or yellow is widespread in the study area.

\section{Materials and methods}

The present investigation was carried out during two successive years (2018 and 2019). Afield experiment was conducted in old areas (one sowing date) at one location was at Dahasa village, Farshut district, Qena governorate, Egypt. Using seven treatments (Balady variety and six maize genotypes) for the evaluation of damage caused by rodent species of maize cultivars. The genotypes studied were three yellow maize (i.e., Balady and Single Cross: Hytech 2055, Hytech 2066) and four white maize [(i.e., (Single cross: Watania 4 and Watania 6) and (three ways cross: Watania 310 and Watania 11)]. Monitoring of rodent species damage in the field, based on the frequency encounter of damage maize corn cob until the harvest time. Direct count method was used in order to determine the rodent damage. Samples of thirty plants were taken randomly from the field of each replicate and damage crops were measured. Half feddan each treatment of maize during two successive years was chosen to this experiment. Samples from each experiment were 30 plants representing five randomized replicates. The degree of damage due to rodent species in the ears was estimated according to Hamelink (1981) by using the following equations:

$$
\begin{aligned}
& 0.0 \times \mathrm{S} 1+ \\
& 0.25 \times \mathrm{S} 2+ \\
& 0.50 \times \mathrm{S} 3+ \\
& 0.75 \times \mathrm{S} 4+ \\
& \text { Damage }(\%)=\frac{1.0 \times \mathrm{S} 5}{\mathrm{~N}} \times 100
\end{aligned}
$$

Where: $\mathrm{S} 1=$ Number of undamaged corn cob; $S 2=$ Number of $1 / 4$ damaged corn cob; $\mathrm{S} 3=$ Number of $1 / 2$ damaged corn cob; $S 4=$ Number of $3 / 4$ damaged corn cob; S5 = Number of complete damaged corn cob; $\mathrm{N}=$ Total Number of investigated corn cob.

Data were analyzed according standard procedures for analysis of variance Duncan's (1955) and (Steel and Torrie, 1980). 


\section{Results and Discussion}

The results presented in Tables (1 and 2) and (Figure 1) indicated that, the highest damage caused by rodent species in the Yellow Maize was observed in (Balady) it was $20.50 \%$ and $19.50 \%$ followed by (Hytech 2066) it was $17.00 \%$ and $15.17 \%$ followed by (Hytech 2055) it was 14.83 and $13.50 \%$ at the first and second years respectively. While the moderate rat of infestation was recorded in the White Maize, (Watania 11) with mean of damage $11.50 \%$ and $11.00 \%$ followed by (Watania 310) it recorded $10.83 \%$ and $9.67 \%$ as damage at the first and second years respectively. While the least rat infestation was recorded in (Watania 6) it was $4.83 \%$ and $4.50 \%$ followed by (Watania 4) it was $6.17 \%$ and $6.00 \%$ in the first and second years respectively. AboHashem (1998) revealed that monthly percentages of rodent losses for tomato and maize both as summer crops. Monthly damage appraisal was fluctuated from month to another.

Table (1): Percentages of damage caused by rodent species in some cultivars of the maize at Qena governorate, Egypt (2018).

\begin{tabular}{|l|l|c|c|c|c|c|c|c|}
\hline \multirow{2}{*}{ Cultivars } & \multicolumn{7}{|c|}{ Damage (\%) } \\
\cline { 2 - 9 } & 1 & 2 & 3 & 4 & 5 & Min. & Max. \\
\hline \multirow{3}{*}{ Yellow Maize } & Balady & 25.83 & 13.33 & 26.67 & 20.00 & 16.67 & 13.33 & 26.67 \\
\cline { 2 - 9 } & Hytech 2055 & 19.17 & 12.50 & 15.00 & 11.67 & 15.83 & 11.67 & 19.17 \\
\cline { 2 - 9 } & Hytech 2066 & 20.00 & 13.33 & 16.67 & 16.67 & 18.33 & 13.33 & 20.00 \\
\hline \multirow{3}{*}{ White Maize } & Watania 11 & 16.67 & 16.67 & 11.67 & 8.33 & 9.17 & 8.33 & 16.67 \\
\cline { 2 - 9 } & Watania 310 & 8.33 & 10.83 & 13.33 & 11.67 & 10.00 & 8.33 & 13.33 \\
\cline { 2 - 9 } & Watania 4 & 10.83 & 5.00 & 4.17 & 2.50 & 8.33 & 2.50 & 10.83 \\
\cline { 2 - 9 } & Watania 6 & 5.83 & 5.00 & 5.00 & 5.00 & 3.33 & 3.33 & 5.83 \\
\hline
\end{tabular}

Table (2): Percentages of damage caused by rodent species in some cultivars of the maize at Qena governorate, Egypt (2019).

\begin{tabular}{|l|l|c|c|c|c|c|c|c|}
\hline \multirow{2}{*}{ Cultivars } & \multicolumn{7}{|c|}{ Damage (\%) } \\
\cline { 3 - 9 } & & 1 & 2 & 3 & 4 & 5 & Min. & Max. \\
\hline \multirow{3}{*}{ Yellow Maize } & Balady & 22.50 & 15.83 & 20.00 & 18.33 & 20.83 & 18.33 & 22.50 \\
\cline { 2 - 9 } & Hytech 2055 & 14.17 & 10.83 & 15.00 & 11.67 & 15.83 & 11.67 & 15.83 \\
\cline { 2 - 9 } & Hytech 2066 & 15.83 & 13.33 & 16.67 & 15.00 & 15.00 & 13.33 & 16.67 \\
\hline \multirow{3}{*}{ White Maize } & Watania 11 & 12.50 & 10.83 & 14.17 & 7.50 & 10.00 & 7.50 & 14.17 \\
\cline { 2 - 9 } & Watania 310 & 10.83 & 9.17 & 9.17 & 9.17 & 10.00 & 9.17 & 10.83 \\
\cline { 2 - 9 } & Watania 4 & 7.50 & 2.50 & 9.17 & 5.83 & 5.00 & 2.50 & 9.17 \\
\cline { 2 - 9 } & Watania 6 & 5.00 & 2.50 & 5.83 & 4.17 & 5.00 & 2.50 & 5.83 \\
\hline
\end{tabular}

Generally, from data in Tables 1 and 2) and (Figure 1) we came revealed that, the Balady variety gave high damage caused by rodents compared to the other genotypes single and three crosses of maize crop. This may be due to maturating early (80:90 days) than other maize cultivars (110: 120 days). The genotypes single cross (Watania 6 and Watania 4 cultivars) gave low damage of 
maize crop. Also, the highest damage was in the varieties of yellow maize with mean 17.45 and $16.06 \%$ at the first and second years respectively. But the lowest damage was in the varieties of white maize with mean 8.33 and $7.79 \%$ at the first and second years respectively._This may be to the high percent of oil and vitamin in seeds of yellow maize cultivars than the white maize cultivars.



Figure (1): Comparisons between percentages of damage caused by rodent species in some cultivars of the maize at Qena governorate, Egypt during two successive years.

Rodents in general prefer grains of low protein, high carbohydrate and moderate fat or seed of low carbohydrate, high protein and high fats, (Asran et al., 2014).
Maize was exposed to high rodent infestation during the full-size seed stage more than the previous or later stages (Soefy et al., 2020).

Table (3): Percentages of damage caused by rodent species in some cultivars of the maize at Qena governorate, Egypt during two successive years.

\begin{tabular}{|l|l|l|c|c|}
\hline \multirow{2}{*}{ Cultivars / genotypes } & \multicolumn{2}{c|}{ Year / Damage (\%) } \\
\cline { 4 - 5 } & Balady & Balady & 2018 & 2019 \\
\hline \multirow{3}{*}{ Yellow Maize } & \multirow{2}{*}{ Single cross } & Hytech 2055 & $14.83 \mathrm{bc}$ & $19.50 \mathrm{a}$ \\
\cline { 3 - 5 } & & Hytech 2066 & $17.00 \mathrm{ab}$ & $15.17 \mathrm{bc}$ \\
\hline \multirow{3}{*}{ White Maize } & \multirow{2}{*}{ Three ways cross } & Watania 11 & $11.50 \mathrm{c}$ & $11.00 \mathrm{~cd}$ \\
\cline { 3 - 5 } & & Watania 310 & $10.83 \mathrm{c}$ & $9.67 \mathrm{~d}$ \\
\cline { 3 - 5 } & \multirow{2}{*}{ Single cross } & Watania 4 & $6.17 \mathrm{~d}$ & $6.00 \mathrm{c}$ \\
\cline { 3 - 5 } & Watania 6 & $4.83 \mathrm{~d}$ & $4.50 \mathrm{c}$ \\
\hline
\end{tabular}

The same letters are not significantly different by $(\mathrm{P}=0.05)$ according to Duncan's multiple range test. 
In yellow maize, there was no significant difference between Balady and Hyteeh 2066, also Hyteeh 2055 and Hyteeh 2066 but there was a significant difference between Balady and Hyteeh 2055. While in white maize, there was no significant difference between (Single cross, Watania 11 and Watania 310, also (three way cross, Watania 4 and Watania 6 but there was a significant difference between single cross and three way cross (Table 3 ). These results are in agreement of that obtained by Embarak (1997), AbdelGawad (1979) and Ahmed (2006).

\section{References}

Abdel-Gawad, K. H. (1979), Studies on the interrelation between rodents and their ectoparasites in the cultivated and semi-arid zones, Ph.D. Thesis, Faculty of Agriculture, Assiut University, Assiut, Egypt, pp. 141.

Abdel-Gawad, K. H., Farghal, A. I., ElEraky, S. A. and Abazaid, A. A. (2000), Damage caused by rodents to some field crops and date palm, The $2^{\text {nd }}$ Scientific Conference of Agricultural Sciences, Faculty of Agriculture, Assiut University, Assiut, Egypt.

Abo-Hashem, A. A. M. (1998), Ecological and toxicological studies on some rodents in anew reclaimed area in Egypt, M.Sc. Thesis, Faculty of Agriculture, Al-Azhar University, Egypt, pp.128.
Ahmed, H. S. K. (2006), Studies on damage caused by rodents on some field crops and its control in Upper Egypt (Assiut area), M.Sc. Thesis, Faculty of Agriculture, Al-Azhar University, Egypt, pp. 109.

Asran, A. A. A., Al-Gendy, A. A. R. and Khaleal, K. E. (2014), "Food preference for albino rat and albino mice under laboratory conditions", Egyptian Journal of Agricultural Research, Vol. 92 No. 4, pp. 12791290.

Baghdadi, S. A. S. (2012), Using of some environmentally available alternatives as rodenticides in Assiut area, Ph.D. Thesis, Faculty of Agriculture, Al-Azhar University, Egypt, pp. 149.

Clark, W. R. and Young, R. E. (1986), Crop damage by small mammals in no-till corn fields, Journal of Soil and Water Conservation, Vol. 41 No. 5, pp. 338-341.

Desoky, A. S. S. (2018), "Rodent damage in maize fields and their control", Acta Scientific Agriculture, Vol. 2 No. 7, pp. 53-54.

Duncan's, D. B. (1955), "Multiple ranged multiple F-test", Biometrics, Vol. 1, pp. 1-17.

El-Saady-Maha, A. (2009), Studies on rodents and its integrated control in Minia region, Ph.D. Thesis, Faculty of Agriculture, Minia University, Minia, Egypt, pp. 160. 
Embarak, M. Z. (1997), Ecological, control studies on Rodents and their ectoparasites in cultivated and Newly Reclaimed area, M.Sc. Thesis, Faculty of Agriculture, Assiut University, Assiut, Egypt, pp. 130.

Fiedler, L. A. (1994), Rodent pest management in Eastern Africa, FAO Plant Production and Protection Paper No. 123, Rome, Italy.

Hamelink, J. (1981), "Assessing rat damage and yield losses in sugar cane, rice and maize", Rodent pests and their control, G.T.Z., A.I-III B/5.

Keshta, T. M. S. (1996), Studies on the house mouse Mus musculus L., M.Sc. Thesis, Faculty of Agriculture, AlAzhar University, Cairo, Egypt, pp. 164.

Metwally, A. M., Montasser, S. A. and Al-Gendy, A. A. R. (2009), "Survey of rodent species and damage assessment caused by Meriones shawi isis (Thomas) in some field crops at Bustan area", Journal of Applied Sciences Research, Vol. 5 No. 1, pp. 40-45.
Mulungu, L. S., Rhodes, H. M., Apia, W. M., Ropert, S. M., Victoria, N. and Herwig, L. (2005), "Spatial patterns and distribution of damage in maize fields due to mastomys natalensis in Tanzania", Belgian Journal of Zoology, Vol. 135, pp. 183-185.

Soefy, W. S., Kashta, T. M. S. and AlGendy, A. A. R. (2020), "Rodents survey and their estimation to some main field crops in two different location at Giza governorate", Egyptian Journal of Applied Sciences, Vol. 35 No. 5, pp. 29-38.

Steel, R. D. D. and Torrie, J. D. (1980), Principle and procedures of statistics, Mcgrow-Hill Book, Co., New York, USA, pp. 481. 